\title{
Disaster-Related Environmental Health Hazards: Former Lead Smelting Plants in the United States
}

\author{
Yao Wang; Robert K. Kanter, MD
}

\section{ABSTRACT}

Objective: Natural disasters exacerbate risks of hazardous environmental exposures and adverse health consequences. The present study determined the proportion of previously identified lead industrial sites in urban locations that are at high risk for dispersal of toxic chemicals by natural disasters.

Methods: Geographic analysis from publicly available data identified former lead smelting plants that coincide with populated urban areas and with high-risk locations for natural disasters.

Results: From a total of 229 urban smelting sites, 66 (29\%) were in relatively high-risk areas for natural disasters: flood (39), earthquake (29), tornado (3), and hurricane (2). States with urban sites at relatively high risk for natural disaster included California (15); Pennsylvania (14); New York (7); Missouri (6); Illinois (5); New Jersey (4); Kentucky (3); Florida, Oregon, and Ohio (2 each); and Indiana, Massachusetts, Rhode Island, Texas, Utah, and Washington (1 each). Incomplete historical records showed at least 10 smelting site locations were affected by natural disaster.

Conclusions: Forgotten environmental hazards may remain hazardous in any community. Uncertainty about risks in disasters causes disruptive public anxiety that increases difficulties in community responses and recovery. Our professional and public responsibility is to seek a better understanding of the risks of latent environmental hazards. (Disaster Med Public Health Preparedness. 2014;8:44-50)

Keywords: exposure, hazard analysis, geographic analysis, latent risks, toxic chemicals, urban

$\mathrm{R}$ esidential proximity to environmental toxic chemicals may be associated with adverse health effects. ${ }^{1}$ Natural disasters, including storms, floods, and earthquakes, are known to exacerbate risks of hazardous environmental exposures and adverse health consequences. ${ }^{2-5}$ Lead has long been a high priority for public health interventions because of its known severe human toxicity, especially for children. ${ }^{6}$

After a tornado caused severe damage in a former lead mining community, practicing pediatricians and public health officials began surveillance for suspected toxic exposure of children resulting from dispersal of underground lead by disruption of trees and building foundations (R.K.K. written communication). ${ }^{7-11}$ The possibility that lead exposure from an environmental source complicated a recent natural disaster raised questions regarding the extent of health risks at former lead-related industrial sites elsewhere. The present study was performed to determine the proportion of previously identified lead industrial sites in populated urban locations ${ }^{12-14}$ that are at high risk for dispersal by natural disasters.

\section{METHODS}

Locations of former lead-related industrial sites were identified that coincide with high population-dense urban areas and with high-risk locations for natural disasters, including tornados, floods, hurricanes, and earthquakes. Natural disasters occurring at these sites were regarded as likely to disperse environmental toxic chemicals and increase the potential for human exposure.

\section{Lead Smelting Plants}

Sites of secondary lead smelting plants (historically involved in recovery of lead from scrap) at 623 locations in the United States had been previously identified from industrial directories. ${ }^{12}$ Exact addresses for 232 of these sites were determined from local historical records, ${ }^{13,14}$ and this published data set was used as a convenience sample for the present study. A geographic information system (ArcGIS, ESRI) was used as a reference for street addresses. For addresses that were not recognized, recent street maps were consulted, and adjacent recognizable addresses were used to approximate the location. One site was excluded because its location overlapped with another 


\section{TABLE}

\begin{tabular}{|c|c|c|c|c|c|c|c|c|}
\hline \multirow{3}{*}{ Relative Risk } & \multicolumn{2}{|l|}{ Flood } & \multicolumn{2}{|l|}{ Hurricane } & \multicolumn{2}{|l|}{ Tornado } & \multicolumn{2}{|l|}{ Earthquake } \\
\hline & Risk Category & No. of Sites & Risk Category & No. of Sites & Risk Category & No. of Sites & Risk Category & No. of Sites \\
\hline & $\begin{array}{l}\text { 100-y Risk } \\
\text { Zone }\end{array}$ & & $\begin{array}{l}\text { No. of Events } \\
\text { per County } \\
(1900-2011)\end{array}$ & & $\begin{array}{l}\text { No. of Events } \\
\text { per County } \\
(1952-2010)\end{array}$ & & $\begin{array}{l}\text { Peak Ground } \\
\text { Acceleration, } \\
\% \text { Gravity } \\
\text { Probability } \\
(>2 \% / 50 \text { y) }\end{array}$ & \\
\hline High & In zone & 39 & $\begin{array}{l}>20 \\
15-19 \\
10-14\end{array}$ & $\begin{array}{l}1 \\
1 \\
0\end{array}$ & $\begin{array}{r}181-210 \\
151-180 \\
121-150 \\
91-120\end{array}$ & $\begin{array}{l}1 \\
0 \\
2 \\
0\end{array}$ & $\begin{array}{c}120-160 \\
80-120 \\
60-80 \\
50-60 \\
40-45 \\
30-40 \\
20-30 \\
18-20\end{array}$ & $\begin{array}{c}0 \\
4 \\
11 \\
1 \\
2 \\
0 \\
11 \\
0\end{array}$ \\
\hline Low & Not in zone & 190 & $\begin{array}{c}4-9 \\
<4 \\
0\end{array}$ & $\begin{array}{c}11 \\
37 \\
179\end{array}$ & $\begin{array}{r}61-90 \\
31-60 \\
11-30 \\
0-10\end{array}$ & $\begin{array}{c}3 \\
44 \\
97 \\
82\end{array}$ & $\begin{array}{c}16-18 \\
14-16 \\
12-14 \\
10-12 \\
8-10 \\
6-8 \\
4-6\end{array}$ & $\begin{array}{c}35 \\
1 \\
11 \\
44 \\
21 \\
47 \\
36\end{array}$ \\
\hline
\end{tabular}

site, leaving 231 for analysis. Although most of these former industrial sites are no longer in operation, soil at many of the sites has been confirmed to contain unremediated toxic levels of lead. ${ }^{12-14}$

\section{Urban Locations}

Lead smelting plants were included for further analysis as potential sources of human exposure if they were located less than 1 mile from concentrated populations. These included urbanized areas (census blocks with $>1000$ people/sq mile) or urban clusters (census blocks with $>500$ people/sq mile adjacent to urbanized areas). ${ }^{15}$ Locations of urban areas were visualized on a geographic information system (ArcGIS, ESRI) and compared with locations of former lead smelting plants.

\section{Natural Disasters}

Areas at high risk for flooding were categorized on the basis of historical records as having a $1 \%$ annual probability of flooding, with areas classified as either within or outside of the 100-year flood zone. ${ }^{16-18}$ Historical hurricane records for coastal counties were used to determine hurricane risk areas in 6 categories, expressed as the total number of hurricanes involving the county in historical records through 2010.19 Partial records of the paths of actual hurricane strikes were also obtained. ${ }^{20}$
Tornado-risk area by county was expressed as the total number of tornado events per county between 1952 and 2010 in 8 categories. ${ }^{21}$ Partial historical records of the paths of actual tornado strikes were also obtained. ${ }^{22}$ For earthquakes, seismic hazards in 17 risk categories were expressed as peak ground acceleration as percent of gravity, with probabilities exceeding $2 \%$ in 50 years. $^{23}$

\section{Disaster Risk for Each Smelting Site}

For each type of natural disaster, maps of smelting plant sites in urban locations were overlapped with disaster risk categories. Relative risk categories were considered low for the lowest risk half of categories and high for the highest risk half of categories. This study of publicly available data with no identifiable subjects or interventions was considered exempt from review by the institutional review board for the protection of human subjects at State University of New York Upstate Medical University.

\section{RESULTS}

\section{Urban Locations}

Among 231 lead smelting sites across the United States, 229 were located within or immediately adjacent to urban concentrations of population. The Table details the number of urban smelting sites according to their risk category for each type of natural disaster. Among the 229 smelting sites in urban 


\section{FIGURE}

\section{Former Lead-Smelting Sites at Risk for Flooding Inside (Triangles) and Outside (Circles) the New York Metropolitan Region Flood Zone (Shading).}

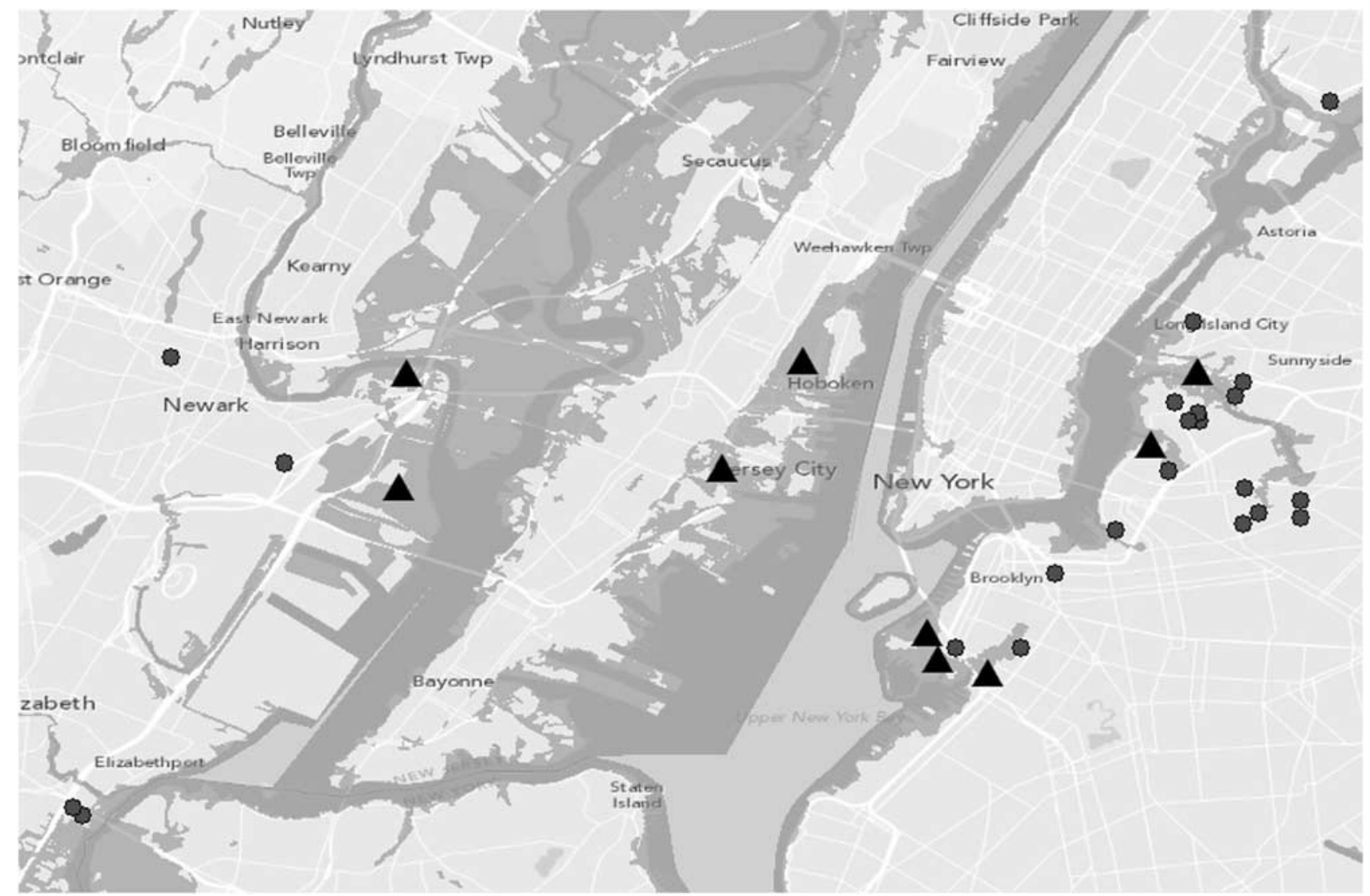

locations, 39 (17\%) coincided with 100-year flood hazard areas. These sites were located near coastal regions, lakes, or streams.

As an example, Figure 1 shows geographical detail for areas at high risk for flooding in the New York City Metropolitan area. Figure 2 shows national locations of former smelting sites at high risk for flooding. Although the geographic detail cannot be seen on a national map, locations with sites at high risk are indicated. Two smelting sites were located in coastal areas at high risk for frequent hurricane activity (Figure 3 ). Three smelting sites were located within a region at high risk for tornados (Figure 4). Earthquake risk was noted for 29 smelting sites $(13 \%)$ in areas most vulnerable to damage along the West Coast (Figure 5).

\section{Disaster Risk for Each Smelting Site}

Of the total sample of 229 sites, 66 urban smelting sites (29\%) were in areas at relatively high risk for natural disasters. Five sites were located in relatively high risk areas for 2 types of disasters, while 1 site was in the high-risk category for 3 types of disasters. States with urban sites at relatively high risk for natural disaster (number of sites) included California (15); Pennsylvania (14); New York (7); Missouri (6); Illinois (5); New Jersey (4); Kentucky (3); Florida, Oregon, and Ohio ( 2 each); and Indiana, Massachusetts, Rhode Island, Texas, Utah, and Washington (1 each).

Historical records showed that 10 smelting sites were in locations actually affected by natural disasters. One site was directly in the path of a tornado in Atlanta, Georgia, in March 2008. ${ }^{24}$ In St Louis, Missouri, and East Saint Louis, Illinois, 4 sites were in the paths of tornadoes in 1896, 1927, 1959, and 2007. ${ }^{25,26}$ During the Ohio River flood in March 1997, two sites in Louisville, Kentucky, and 2 sites in Cincinnati, Ohio, were directly affected. ${ }^{27,28}$ Hurricane Agnes in 1972 caused widespread flooding in Pennsylvania, including 1 site in Harrisburg. ${ }^{29,30}$ Incomplete information is available on the extent of damages due to natural disasters, and additional sites may have been involved.

\section{DISCUSSION}

Our approach to identifying risks may inform regional disaster preparedness hazard analyses ${ }^{31}$ and provide an additional 
FIGURE 2

Former Lead Smelting Sites at High (Triangles) and Low (circles) Risk for Flooding Nationally.

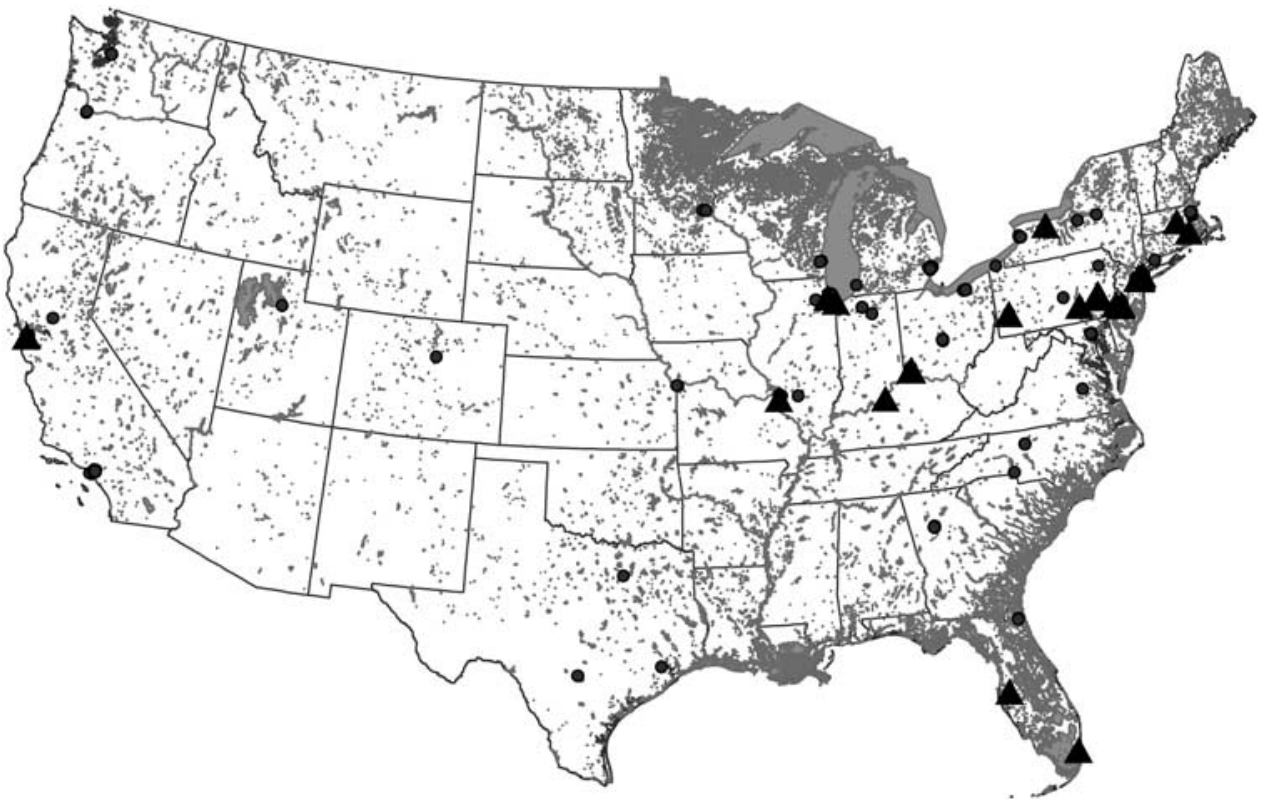

Flood zones are shaded. Overlapping location markers indicate multiple sites within the same city.

\section{FIGURE 3}

Former Lead Smelting Sites at High (Triangles) and Low (Circles) Risk for Hurricane Exposure.

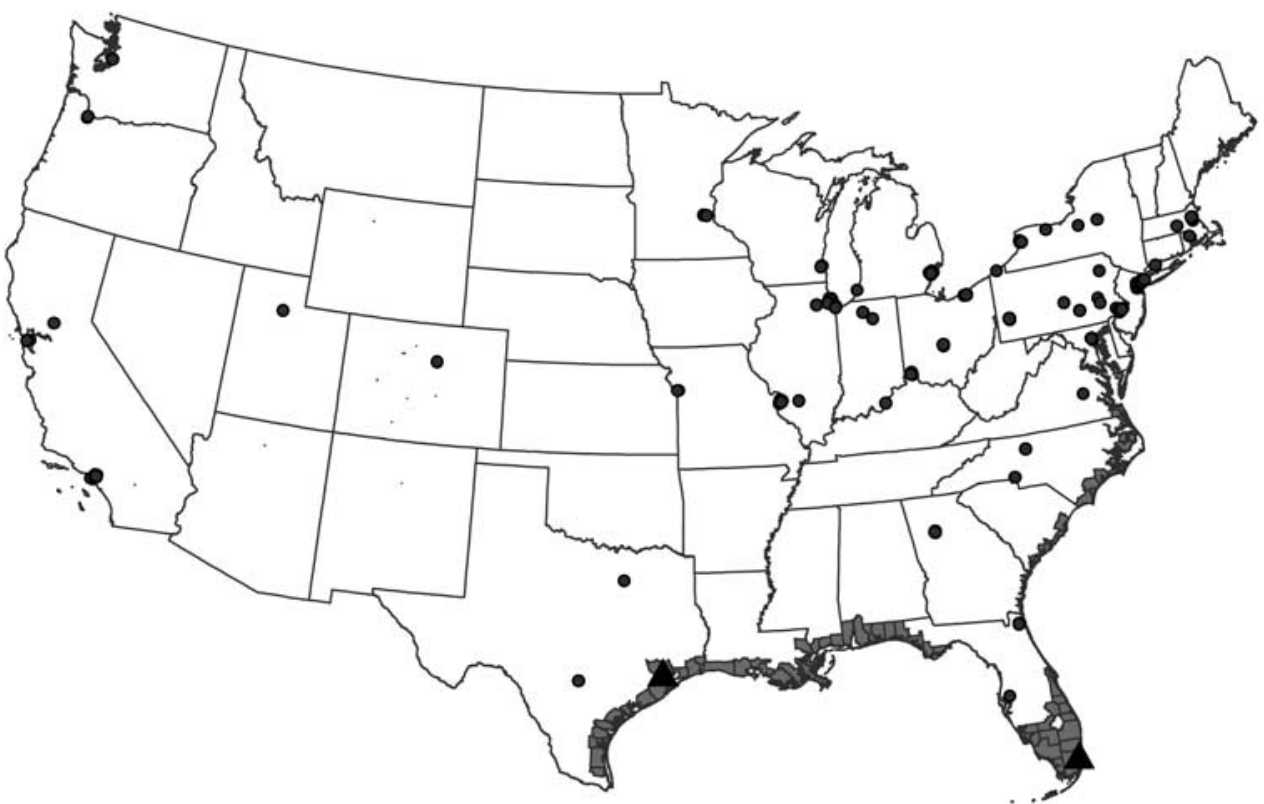

Hurricane high-risk areas are shaded. Overlapping location markers indicate multiple sites within the same city.

incentive for cleanup priorities for sites contaminated by lead or other toxic chemicals whose implications for human health are less well understood. ${ }^{32}$ Knowledge of point source locations of concentrated toxic chemicals may guide postdisaster public health surveillance, potentially improving timeliness of interventions when warranted. ${ }^{2-5}$ 
FIGURE 4

Former Lead Smelting Sites at High (Triangles) and Low (Circles) Risk for Tornado Exposure.

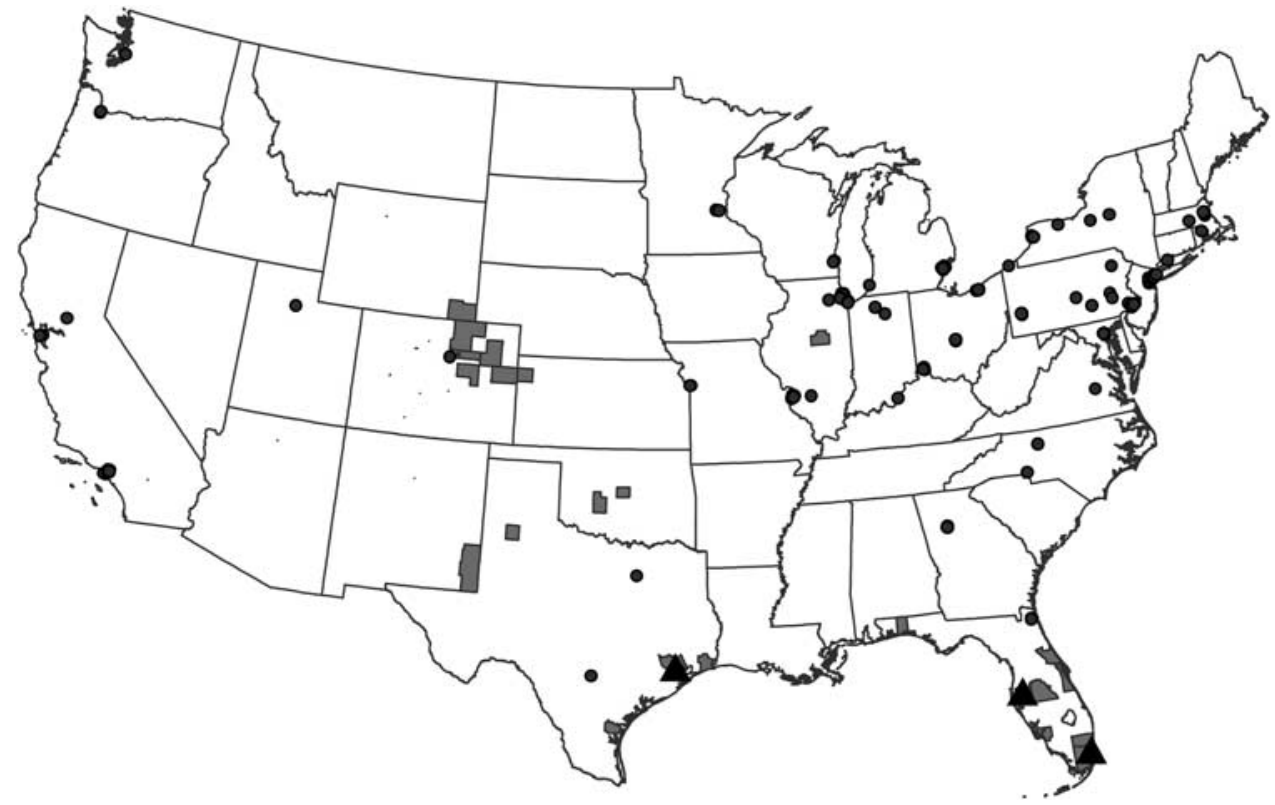

Tornado high-risk areas are shaded. Overlapping location markers indicate multiple sites within the same city.

\section{FIGURE 5}

Former Lead Smelting Sites at High (Triangles) and Low (Circles) Risk for Earthquakes.

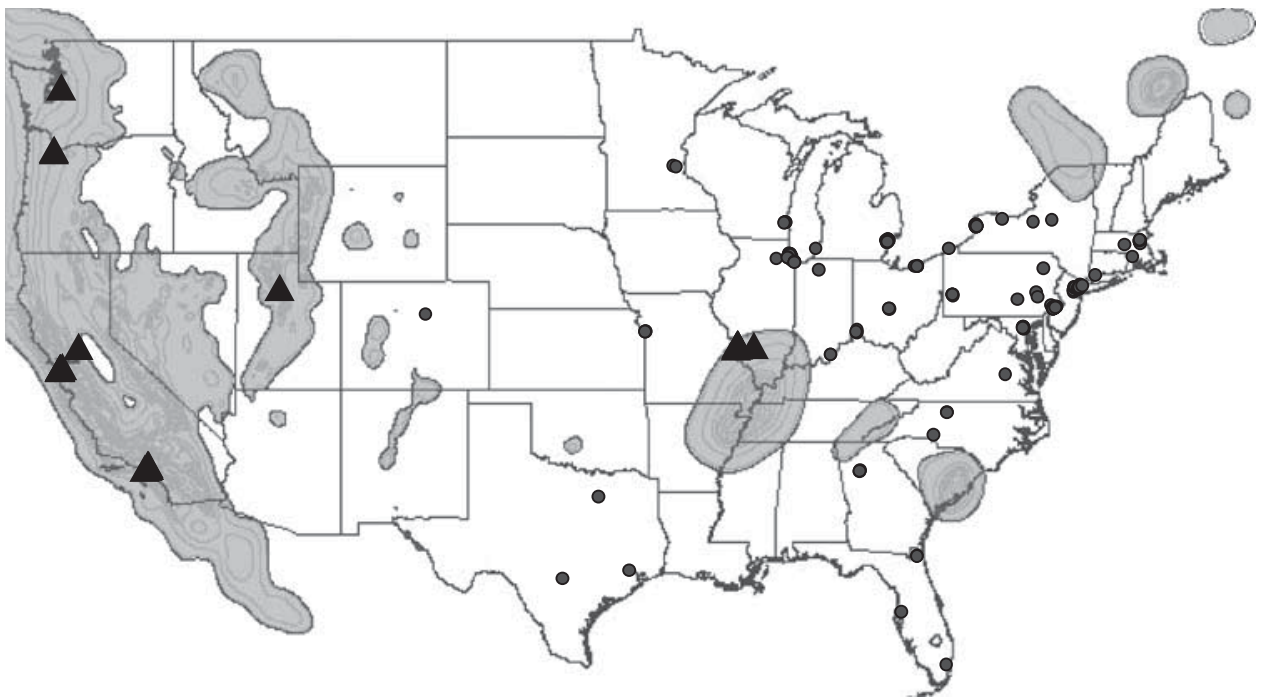

Earthquake high-risk areas are shaded. Overlapping location markers indicate multiple sites within the same city.

Natural disasters have the potential to exacerbate latent environmental hazards. Disruption of foundations under buildings may bring buried toxic material to the surface, and disruption of soil may uncover buried toxic deposits, even in areas that had toxic material covered in previous mitigation programs. In addition, wind or flooding may disperse exposed toxic material to downstream locations. As a result, human health effects of environmental hazards after 
disasters are difficult to predict. For example, soil lead actually declined in samples from 29 of 46 census tracts after hurricanes Katrina and Rita in New Orleans, with accompanying declines in blood lead levels in children. ${ }^{33}$ The fortunate decline in local lead exposures after hurricanes Katrina and Rita was attributed to flooding that deposited uncontaminated sediment and buried previous contamination. However, such favorable random effects cannot be depended on in future disasters. Facing uncertainty and lacking professional or public health guidance, a concerned neighborhood group in New York initiated its own environmental testing for toxic chemicals after Hurricane Sandy in $2012 .^{34}$

\section{Limitations}

The classification method used to identify high-risk areas was, we believe, an unbiased approach. It was designed for the present study to provide a single description of locations with historical levels of risk. The classification discriminated the top versus the lowest half of risk categories applied across various types of natural disasters, where each type of disaster has distinct measures of frequency and severity. Limitations of our data included the nonrepresentative convenience sample of smelting plants, the arbitrary criteria for the high-risk category of disaster locations, and the low frequency of high consequence events in the historical record common to all data on natural disasters.

Finally, it is important to note that former lead smelting plants at high risk for natural disaster are a convenience sample representing only a single toxic material. Other types of latent environmental hazards may have entirely different geographical distributions. To conduct a hazard analysis in a specific community, local evidence regarding risk of specific natural disasters, at a threshold set by local decision makers, must be matched with known locations of specific latent environmental hazards. To identify potential sources of contamination after an actual disaster, involved and damaged areas must be matched with known locations of specific latent environmental hazards.

\section{CONCLUSIONS}

The findings of our study serve to remind clinicians, clinical researchers, and public health officials that forgotten environmental hazards may remain hazardous in any community. Clinicians and public health officials are increasingly asked by the public for guidance in managing disaster-related environmental hazards. ${ }^{34}$ Uncertainty about risks in disasters heightens disruptive public anxiety that increases difficulties in community responses and recovery. ${ }^{35}$ We believe that it is our professional and public responsibility to seek a better understanding of the risks of latent environmental hazards in disasters.

\section{About the Authors}

College of Medicine (Ms Wang), and Division of Pediatric Critical Care Medicine (Dr Kanter), State University of New York, Upstate Medical University, Syracuse; and National Center for Disaster Preparedness, Columbia University, New York (Dr Kanter), New York.

Correspondence and reprint requests to Robert K. Kanter, MD, Division of Pediatric Critical Care Medicine, Department of Pediatrics, 750 E Adams St, Syracuse, NY 13210. (e-mail: kanterr@upstate.edu).

\section{Acknowledgments}

Myrna H. Hall, PhD, and Liyang Shao, provided invaluable advice and assistance with the geographical analysis.

\section{Supplementary material}

To view supplementary material for this article, please visit $h t t p: / / d x$.doi.org/ $10.1017 / d m p .2014 .3$

Published online: February 24, 2014.

\section{REFERENCES}

1. Brender JD, Maantay JA, Chakraborty J. Residential proximity to environmental hazards and adverse health outcomes. Am J Public Health. 2011;101:S37-S52.

2. Wisner B, Adams J. Environmental Health in Emergencies and Disasters: A Practical Guide. Geneva Switzerland: World Health Organization; 2003.

3. Sengul H, Santella N, Steinberg LJ, Cruz AM. Analysis of hazardous material releases due to natural hazards in the United States. Disasters. 2012;36(4):723-743.

4. Alderman K, Turner LR, Tong S. Floods and human health: A systematic review. Environ Int. 2012;47:37-47.

5. Ratnapradipa D, Conder J, Ruffing A, White V. The 2011 Japanese earthquake: an overview of environmental health impacts. J Environ Health. 2012;74:42-50.

6. US Environmental Protection Agency. Addressing lead at superfund sites. Washington, DC: US Environmental Protection Agency; 2012. http://www.epa.gov/superfund/health/contaminants/lead/index.htm. Accessed August 9, 2012.

7. Map shows lead contamination in Joplin, MO. Ozarksfirst.com; October 11, 2011. http://www.ozarksfirst.com/story/map-shows-lead-contaminationin-joplin-mo/d/story/3xxq_yRSnEe-EVLLaFHqqA. Accessed April 19, 2012.

8. Sampson M. Joplin tornado uncovers potentially deadly hazard. The Weather Channel; November 3, 2011. http://www.weather.com/outlook/ weather-news/news/articles/joplin-tornado-lead-contamination_2011-11-03. Accessed July 6, 2012.

9. Davidson J. Joplin health officials finding lead contamination in tornado soil: contamination likely related to the city's history as a lead mining community. KSMU; May 23, 2012. http://ksmu.org/article/joplin-healthofficials-finding-lead-contamination-tornado-zone-soil. Accessed July 6, 2012.

10. Sheikh J. Two Joplin parks close due to lead contamination. KOAM TV; June 15, 2012. http://www.koamtv.com/story/18802438/two-joplin-parksclose-due-to-lead-contamination? clienttype $=$ printable. Accessed July 6, 2012.

11. Jasper County, Missouri Health Department. Mine waste areas, smelter area and inventory of mining occurrence maps. Carthage, MO, September 13, 2012. Jasper County website.

12. Eckel WP, Rabinowitz MB, Foster GD. Discovering unrecognized lead-smelting sites by historical methods. Am J Public Health. 2001;91:625-627.

13. Young A. Long-gone lead factories leave poisons in nearby yards. USA Today. April 19, 2012. http://www.usatoday.com/news/nation/story/201204-19/smelting-lead-contamination-government-failure/54399578/1. Accessed April 23, 2012. 
14. Young A, Eisler P. Some neighborhoods dangerously contaminated by lead fallout. USA Today; April 20, 2012. http://www.usatoday.com/news/ nation/story/2012-04-20/smelting-lead-contamination-soil-testing/54420418/ 1. Accessed April 23, 2012.

15. US Census Bureau. Census 2000 urban and rural classification. US Census Bureau website; 2011. http://www.census.gov/main/www/ cen2000.html. Accessed August 26, 2012.

16. Federal Emergency Management Agency. Mapping information platform. Federal Emergency Management Agency website; 2012. https://hazards.fema.gov/femaportal/wps/portal/. Accessed July 5, 2012.

17. Office of the City Administrator. San Francisco floodplain management program. San Francisco, CA: City and County of San Francisco. 2012. http://sfgsa.org/index.aspx?page =828. Accessed July 12, 2012.

18. King County iMAP: Hydrographic information. King County, Washington website; 2012. http://www5 .kingcounty.gov/iMAP/viewer.htm? mapset $=$ wria. Accessed July 13, 2012.

19. National Oceanic and Atmospheric Association (NOAA) Coastal Services Center. Historical hurricane tracks. NOAA Coastal Services Center website; 2012. http://www.csc.noaa.gov/hurricanes/\#. Accessed July 7, 2012.

20. National Oceanic and Atmospheric Association (NOAA). International best track archive for climate stewardship, World Data Center for Meteorology, Silver Spring, MD. http://www.ncdc.noaa.gov/oa/ibtracs/ index.php? name =ibtracs-data. Accessed August 26, 2012.

21. National Oceanic and Atmospheric Association (NOAA). Tornadoes per county, 1952-2010. Norman, OK: National Weather Service Storm Prediction Center; 2012. http://www.spc.noaa.gov/wcm/ustormaps/ tornadoes-by-county.png. Accessed June 25, 2012.

22. National Oceanic and Atmospheric Association (NOAA). Severe weather SVRGIS. Norman, OK: National Weather Service Storm Prediction Center; 2012. http://www.spc.noaa.gov/gis/svrgis/. Accessed August 26, 2012.

23. Petersen MD, Frankel AD, Harmsen SC , et al. Seismic-hazard maps for the conterminous United States, 2008. Reston, VA: US Geological Survey; 2011. http://pubs.usgs.gov/sim/3195/. Accessed July 23, 2012.

24. National Weather Service Peachtree City, GA Weather Forecast Office. The Atlanta tornado March 14, 2008. Peachtree City, GA: National Weather Service; 2010. http://www.srh.noaa.gov/ffc/?n=atltor31408. Accessed July 19, 2012.
25. National Weather Service St.Louis, MO Weather Forecast Office. 50-Year anniversary of the February 10th 1959 St. Louis tornado. St.Louis, MO: National Weather Service; 2010. http://www.crh.noaa.gov/ $l s x / ? n=02 \_10 \_1959$. Accessed July 19, 2012.

26. National Weather Service St.Louis, MO Weather Forecast Office. Bow Echo event over the city of St. Louis, Missouri March 31st, 2007. St.Louis, MO: National Weather Service; 2009. http://www.crh.noaa.gov/ $l s x / ? n=03 \_31 \_2007$. Accessed July 19, 2012.

27. National Weather Service Louisville, KY Weather Forecast Office. The Flood of March 1997. Louisville, KY: National Weather Service; 2007. http://www.crh.noaa.gov/lmk/?n=flood97. Accessed Aug 8, 2012.

28. Scott Jackson K, Vivian SA. Flood of March 1997 in Southern Ohio. Columbus, Ohio: US Geological Survey; 1998. http://oh.water.usgs.gov/ reports/Flood/flood.rpt.html\#HDR8. Accessed August 8, 2012.

29. National Weather Service Middle Atlantic River Forecast Center. Hurricane Agnes. State College, PA: National Weather Service; 2006. http://www.erh.noaa.gov/er/marfc/Flood/agnes.html. Accessed August 10, 2012.

30. Lyudmilov Y. Cities under water, under siege: Hurricane Agnes. University Park, PA: The Pennsylvania State University; 2010. http:// pabook.libraries.psu.edu/palitmap/Agnes.htm. Accessed August 10, 2012.

31. Gamboa-Maldonado T, Marshak HH, Sinclair R, Montgomery S, Dyjack DT. Building capacity for community disaster preparedness: a call for collaboration between public environmental health and emergency preparedness and response programs. J Environ Health. 2012;75:24-29.

32. American Academy of Pediatrics Council on Environmental Health. Chemical-management policy: prioritizing children's health. Pediatrics. 2011;127:983-990.

33. Zahran S, Mielke HW, Gonzales CR, Powell ET, Weiler S. New Orleans before and after Hurricanes Katrina/Rita: a quasi-experiment of the association between soil lead and children's blood lead. Environ Sci Technol. 2010;44:4433-4440.

34. Barry R, Searcey D, Carreyrou J. Sandy stirs toxic-site worry. Wall Street Journal November 12, 2012.

35. Meredith LS, Eisenman DP, Tanielian T, et al. Prioritizing "psychological" consequences for disaster preparedness and response: a framework for addressing the emotional, behavioral, and cognitive effects of patient surge in large scale disasters. Disaster Med Public Health Prep. 2011; 5:73-80. 